\title{
Evaluating net community benefits of integrating nature within cities
}

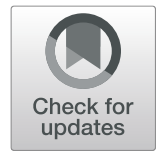

Peter Daniels ${ }^{1}$, Omniya El Baghdadi ${ }^{2}$, C. Desha ${ }^{3^{*}}$ (D) and T. Matthews ${ }^{4}$

\begin{abstract}
Background: There is a lack of support for methods and data systems for the writing and impementation of regulatory and policy improvements requiring the evaluation of the net community benefits of integrating nature into cities. Addressing this need, this paper presents essential context and a framework to guide consistent and systematic assessment of the social benefits and costs of biophilic urbanism and other bases for urban greening. We begin with a review of the major characteristics of, and differences between, key urban greening-related terms given the importance of establishing a consistent analytic basis for wellbeing assessment in urban planning strategies. These terms include 'green cities', 'open space', 'urban green space', 'urban green infrastructure', 'biophilia' and the practice of 'biophilic urbanism'.

Results: We propose the use of 'biophilic urbanism' as a rubric urban planning term to cover all of the urban environmental interventions involving the intentional provision or protection of biophysical features. Focusing on specific and strategic targets and implementation actions, we then explore the consolidation and methodical assessment of social benefits and costs associated with the benefits of biophilic urbanism, based on total economic value (TEV) conceptual framework and its ability to support net environmental benefit valuation.

Conclusions: We conclude with an emphasis upon the importance of ensuring structure and methodological rigour in budgets and performance evaluation requirements. This paper has immediate implications for policy makers and regulatory authorities, providing the basis for consistent and transparent evaluation of biophilic urbanism initiatives. It also has implications for urban planners and built environment professionals, highlighting key considerations for design briefs to ensure the adequate integration of nature into urban new-build, refurbishments and revitalisation efforts.
\end{abstract}

Keywords: Urban greening, Biophilic urbanism, Biophilic services, Total economic value, Ecosystem services

\section{Plain English summary}

There are few existing studies that review the various urban greening-related terms and their characteristics and benefits, despite the importance of establishing this analytic basis for wellbeing assessment in urban planning strategies. This confusion of terminologies limits understanding of the full impact - what we refer to as net community benefits - of urban greening. This paper aims to address this gap by contributing the following:

\footnotetext{
* Correspondence: c.desha@griffith.edu.au

${ }^{3}$ Cities Research Institute, Griffith University, 170 Kessels Road, Nathan, QLD 4111, Australia

Full list of author information is available at the end of the article
}

- Consolidation of urban greening-related terms An overview of the various concepts used to describe nature in cities. This includes the terms 'green cities', 'urban green space', 'open space', 'urban green infrastructure', and 'biophilic urbanism'. This clarification of concepts is critical as the basis for consolidating concepts to develop a systematic and structured methodological approach for understanding and assessing the net community benefits, or positive social, economic and environmental impacts, of urban greening.

- Biophilic Urbanism as an overarching term to describe nature in cities - This paper presents the

(c) The Author(s). 2020 Open Access This article is licensed under a Creative Commons Attribution 4.0 International License, which permits use, sharing, adaptation, distribution and reproduction in any medium or format, as long as you give appropriate credit to the original author(s) and the source, provide a link to the Creative Commons licence, and indicate if changes were made. The images or other third party material in this article are included in the article's Creative Commons licence, unless indicated otherwise in a credit line to the material. If material is not included in the article's Creative Commons licence and your intended use is not permitted by statutory regulation or exceeds the permitted use, you will need to obtain permission directly from the copyright holder. To view a copy of this licence, visit http://creativecommons.org/licenses/by/4.0/. 
evolution of the concepts from an instrumental, practical, aesthetically driven approach to a concept that considers wellbeing. This evolution of the benefits of nature in cities is best reflected in biophilic urbanism, which captures the functional, wellbeing and even economic benefits of nature in cities. It explains how biophilic elements can positively impact a city's economic, environmental and social objectives.

- Biophilic Services to describe net community benefits of nature in cities - The paper builds on the work by el-Baghdadi and Desha (2016) to classify and describe the full breadth of potential benefits and costs that can result from urban greening. We present a detailed table with the full range of mechanisms and impacts of biophilic elements assessed as parts of the ecosystem services functional groupings and categories of the Millennium Ecosystem Assessment report. This is completed as a critical step for our forthcoming research findings identifying useful environmental valuation techniques to assess the net community benefits of such actions.

The outcomes of this paper are important in helping to facilitate urban planning decision-making capabilities to mainstream strategic and appropriate integration of nature in cities.

\section{Introduction}

Urban environments have been very effective in helping to enhance economic welfare and material quality of life in a fertile environment facilitating a host of agglomeration economies, and technological efficiencies and innovation. This has spurred positive feedback loops of growth in economic, transport and communication productivity, and consumption. The world's top 600 cities are projected to account for about $60 \%$ of global GDP in 2025 [1]. It is increasingly recognised that cities need to be designed in a way that contributes to healthy and truly fulfilling lives [2]. The persistence of longstanding environmental problems and the rise of new 'lifestyle' diseases are clear evidence of the welfare failings of urban life. For example, there is a plethora of problems associated with obesity and psychic deficiencies evident in the proliferation of mental illnesses and related ennui and malaise that are borne from and exacerbated by urban living [1]. Building on his foundation text Design with Nature [3], McHarg's subsequent papers and those of other authors such as Louv [4], have highlighted the mounting evidence of the adverse sociopsychological consequences of life immersed in a manufactured world.

There is a strong and growing case that substantive nature connection, as derived from integrated urban greening, will be vital for the long-term wellbeing of the urbanised community. Opportunity exists for integrating nature to address the plethora of urban-related problems, while improving productivity and increasing biodiversity in our urban environments $([3,5-7])$. There is a need to systematically and scientifically inform and redress the potential imbalance and malaise associated with nature disconnect. A key part of this effort has been the focus upon the direct services proffered by urban nature. However, there is an increasing recognition of the need to understand how and why human beings appear to need regular and substantial connection with nature for full psychological and emotional development [8]. Despite political preferences and the shift towards 'urban greenery' and 'living infrastructure', which conceptually includes green, blue and grey infrastructure, green areas remain a peripheral urban priority, especially compared to buildings and transport-related infrastructure.

There are few existing studies that review the essential characteristics and differences between and benefits of various urban greening-related terms, despite the importance of establishing this analytic basis for wellbeing assessment in urban planning strategies. Two important papers by de Ridder et al. [9] and Zhou and Rana [10] discuss the environmental valuation potential of urban greening. De Ridder et al. focus on land use planning, transport and other modelling given different urban greening scenarios and they highlight the importance of accessibility to nature. However their study does not include empirical evidence to support the purported benefits of traffic flow impacts of different urban structures. Furthermore the Ridder et al. paper does not include commentary on social wellbeing aspects that might be expected given the paper's stated aims. In their paper, Zhou and Rana [10b] analyse the benefits of urban green space, limiting the narrative to the social benefits of urban nature. They offer a generic definition of 'urban green space' without offering a comprehensive definition nor a systematic categorisation of the myriad of benefits (i.e. net community benefits) resultant from integrating nature in cities.

This paper builds on the work of these authors. Its key aim is to set the essential context and framework required to guide a consistent and systematic approach to assessing the net community benefits of potential measures for promoting biophilic urbanism and other bases for integrating nature within urban areas. We propose an explicit emphasis on biophilic urbanism and its elements, with more detailed analysis of impacts, related to Total Economic Value (TEV).

We begin with providing a literature review of several key terms, including green cities, urban green space, open space, urban green infrastructure, and biophilic urbanism. We then present a preliminary economic 
framework for assessing the impacts of biophilic urbanism initiatives, followed by an evaluation of opportunities and challenges for evaluation techniques. This is a critical step for our ongoing research into identifying useful environmental valuation techniques to assess the net community benefits of such actions. Finally we discuss how urban planning decision-making could be improved from a deeper analysis and understanding of the benefits and costs of biophilic urbanism. The paper represents an important first step in measuring the social benefits and costs of the full range of biophilic urbanism and related effects inherent in urban greening initiatives. It facilitates the identification, classification and potential measurement and, where possible, the economic valuation and comparison of these effects, to inform the societal 'business case' for various degrees and forms of implementation of biophilic urbanism.

\section{A review of concepts for integrating nature within cities} Over the last few decades, endeavours to embed nature within urban development have tended to focus on 'environmental' opportunities, with biophysical emphasis targeting attributes such as urban metabolism and material and energy flows, as well as other material dimensions of the city as documented by Brunner [11]. Around the same time, seminal authors including Ulrich [12], Ulrich et al. [13] and Kellert and Wilson [14] began documenting the ultimate goals of social sustainability and wellbeing for strategic change and planning. However, there is still considerable lack of clarity regarding the various perspectives and tools related to the integration of nature into cities. Individual concepts and terms are often used interchangeably, yet each has a distinct conceptual character with associated implications for urban design, planning and experience. For example, the term 'eco-city' was first coined by Register in Eco-City Berkeley: Building Cities for a Healthy Future. The origins of the term 'eco-city' also has close ties with the basis of urban ecology, an interdisciplinary field of study that explores the relations of human beings with one another and their surroundings, including the built environment and urbanising landscapes [15].

Analytical consistency regarding the various modes by which nature in cities impacts can occur is critical for the systematic evaluation of the social benefit and costs of urban greening initiatives. Such information is also vital for making good decisions about the social efficiency and net community benefit of the extent and form of nature integration in the built environment. Each approach provides a range of social benefits and has associated costs of implementation, for urban residents and their local community. This can come from directly experiencing connections with natural environment elements, or from indirect biophysical and social effects (such as social interaction and other sociopsychological effects).

In this section, we present the results of a detailed literature review into key vocabulary, to distinguish and relate the range of operational terms for initiatives that involve embedding nature within urban areas. The major characteristics of these various approaches are presented in Table 1, noting that the concepts often overlap and vary between researchers and disciplinary specialisations. Indeed, many are often used interchangeably despite ostensible differences.

\section{Green cities}

Researchers and planners have long-used the concept of 'green cities' to synonymously describe a multitude of ideas and concepts [20], and concepts such as 'sustainable city', 'eco-community', 'low-carbon city' and 'eco city' [49]. It refers to an urban approach focused upon high levels of overall environmental performance of the city as regional entity [16]. The main objective of a 'green city' is to manage natural resources responsibly - not only to prevent or reduce environmental impact but rather to enhance environmental performance.

The term is influenced by various movements such as social ecology, bio-regionalism and the green movement in general [19], making it quite a multi-dimensional concept. It adopts a modern sustainability emphasis which rejects conflictual, trade-off notions of rapid demographic, economic and physical structural change and growth in cities in favour of a complementary view of the associated environmental, social and economic outcomes [17]. Hence, 'green' does not only refer to urban environmental issues, but also considers dynamic social and economic implications [18]. Green city approaches can also include sustainable consumption concepts that link city activity to the rest of the world via supply and integrated chain links (for example, via extended environmental and multiregional input-output analysis). Healthy and safe environments and resilience are other key objectives (with the latter covering aspects such natural disasters, climate change impacts, and the risk of major infectious disease outbreaks [21].

Arguably, the green city movement is city-wide perspective that emphasises the reduction of biophysical material, energy and waste flows between the city and its regional to global hinterland, akin to urban metabolism and material flow accounting frameworks [18]. This approach does have a clear emphasis on liveability and quality of life (and the key influence of environmental quality for this). Nonetheless, immediate indicators for green cities success tend to be overall ecological footprints, Green City Indices, greenhouse gas emissions levels, energy use and type, air and water quality, water and waste flows, green buildings, recycling rates, 
Table 1 An overview of key concepts related to action for integrating nature within cities

\begin{tabular}{|c|c|c|c|c|}
\hline Concept & Definition & Main Purpose / Strategic Intent & Geographic scale & Key Literature \\
\hline Green city & $\begin{array}{l}\text { A general notion of cities adopting } \\
\text { sustainability design and function } \\
\text { principles and actions to reduce } \\
\text { environmental impacts, with less } \\
\text { material, energy and waste flows } \\
\text { and urban metabolism, circular } \\
\text { economies, increased housing } \\
\text { density while expanding open } \\
\text { space, more sustainable local } \\
\text { businesses [16]. }\end{array}$ & $\begin{array}{l}\text { - Multidimensional, responsible } \\
\text { society } \\
\text { - Overall city-wide enhanced } \\
\text { environmental performance } \\
\text { - Improved human well-being } \\
\text { and liveability }\end{array}$ & $\begin{array}{l}\text { - Transformational, } \\
\text { city-wide agenda, } \\
\text { purposeful } \\
\text { implementation } \\
\text { - City Scale within } \\
\text { the context of } \\
\text { environmental impacts } \\
\text { on regional and } \\
\text { broader hinterlands }\end{array}$ & $\begin{array}{l}\text { Zhou and Williams [16]; } \\
\text { Campbell [17]; Lewis [18]; } \\
\text { Roseland [19]; Van Dijk [20]; } \\
\text { UNEP [21]. }\end{array}$ \\
\hline $\begin{array}{l}\text { Urban open } \\
\text { space }\end{array}$ & $\begin{array}{l}\text { Provision of recreational activities, } \\
\text { separate conflicting land-use } \\
\text { function and other externality } \\
\text { reductions, segmentation of } \\
\text { socioeconomic status or other } \\
\text { division localities [22]. }\end{array}$ & $\begin{array}{l}\text { - Provision of recreational activities } \\
\text { - Separation of conflicting land-use } \\
\text { function } \\
\text { - Segmentation of socioeconomic } \\
\text { status or other division localities }\end{array}$ & $\begin{array}{l}\text { - Often incremental, } \\
\text { ad hoc } \\
\text { implementation } \\
\text { - Neighbourhood } \\
\text { to metro scale }\end{array}$ & $\begin{array}{l}\text { Habermas [22]; Hajer and } \\
\text { Reijndorp, [23]; Ihlanfeldt } \\
\text { and Scafidi [24]; Jacobs [25]; } \\
\text { Tibbalds [26]; Sennett, } \\
\text { [27, 28]; Stanley et al. [29]; } \\
\text { Whyte, [30]. }\end{array}$ \\
\hline $\begin{array}{l}\text { Urban green } \\
\text { space }\end{array}$ & $\begin{array}{l}\text { Integrated areas comprising natural, } \\
\text { semi-natural, or artificial green land, } \\
\text { providing manifold benefits to } \\
\text { different groups of people within } \\
\text { the city extent people [30]. }\end{array}$ & $\begin{array}{l}\text { - Create meeting places } \\
\text { - Enhance community connectivity } \\
\text { - Enhance aesthetic value, leisure } \\
\text { and recreation }\end{array}$ & $\begin{array}{l}\text { - Often incremental, } \\
\text { ad hoc implementation } \\
\text { - Neighbourhood } \\
\text { to metro scale }\end{array}$ & $\begin{array}{l}\text { Tzoulas et al., [31]; Jim and } \\
\text { Chen [32]; MacHarg [33]; } \\
\text { van Leeuwan et al. [34]. }\end{array}$ \\
\hline $\begin{array}{l}\text { Urban green } \\
\text { infrastructure }\end{array}$ & $\begin{array}{l}\text { An interconnected network of } \\
\text { multifunctional green-spaces that } \\
\text { are strategically planned and } \\
\text { managed to provide a range of } \\
\text { ecological, social, and economic } \\
\text { benefits [35]. }\end{array}$ & $\begin{array}{l}\text { - Adopts a broad definition of } \\
\text { 'infrastructure' } \\
\text { - Beyond 'constructed' and } \\
\text { technical economic emphasis }\end{array}$ & $\begin{array}{l}\text { - Urban-wide network } \\
\text { connections } \\
\text { - Recognition of the } \\
\text { importance of networks } \\
\text { and interconnectedness } \\
\text { for resilience } \\
\text { - More extensive than } \\
\text { just broad-scale green } \\
\text { 'space' planning. }\end{array}$ & $\begin{array}{l}\text { Matthews et al. [35]; } \\
\text { Benedict \& McMahon [36]; } \\
\text { Byrne \& Yang [37]; CSIRO } \\
\text { [38]; Douglas [39]; Dramstad } \\
\text { et al. [40]; Foster et al. [41]; } \\
\text { Fulmer [42]; Gill et al. [43]; } \\
\text { Hellmund et al. [44]. }\end{array}$ \\
\hline $\begin{array}{l}\text { Biophilic } \\
\text { urbanism }\end{array}$ & $\begin{array}{l}\text { Biophilic urbanism, with its } \\
\text { associated 'biophilic elements' are } \\
\text { the range of urban changes that } \\
\text { are explicitly directed towards } \\
\text { implementing biophilic urbanism } \\
\text { (BU) principles. BU proposes the } \\
\text { incorporation of intentional natural } \\
\text { design features across cities, } \\
\text { neighbourhoods and buildings to } \\
\text { offer daily exposure to natural } \\
\text { systems [44]. }\end{array}$ & $\begin{array}{l}\text { - Philosophical, psychological and } \\
\text { physiological approach to } \\
\text { integrating nature into a city's } \\
\text { fabric } \\
\text { - To enhance net community } \\
\text { wellbeing from the benefits derived } \\
\text { people's innate connection or } \\
\text { immersion in nature } \\
\text { - Ranging from aesthetic and } \\
\text { socio-psychological health benefits } \\
\text { to economic efficiencies related to } \\
\text { improved functional and instrumental } \\
\text { capacities or services of natural systems }\end{array}$ & $\begin{array}{l}\text { - Building scale: } \\
\text { including green roofs } \\
\text { and green walls. } \\
\text { - Neighbourhood scale: } \\
\text { including bio-swales } \\
\text { and green streets. } \\
\text { - City scale: including } \\
\text { urban parks and green } \\
\text { corridors. }\end{array}$ & $\begin{array}{l}\text { Beatley [7, 45]; Desha et al. } \\
\text { [46]; Wilson [47]; Ulrich. } \\
\text { [12]; Kellert [48] }\end{array}$ \\
\hline
\end{tabular}

transport mode use, and eco-efficiency achievements [50]. The resolution for this approach tends to be for the overall urban complex rather than specific micro-level, structural components. However, there is at least an explicit recognition of the importance of infrastructure, and networks and facilitating systems (as in many of the other approaches) and the need for inter-disciplinary perspectives for effectively creating 'green cities'.

Implementation of a green city should encompass plans, measures, operational strategies and technologies to enhance all aspects of economic, social and environmental health. These goals are typically thought to be achieved by conserving natural and less dependency on fossil fuels. This is consistent with reduced automobile use and waste stream flows and other urban metabolic flows, the integration of nature into cities, a shift towards resource-efficient technology use, and building diverse spaces that enhance social equity, and actively support community participation in city improvement efforts [16].

\section{Urban open space}

Urban open space is defined as any urban ground space that is not roofed by building or architectural structure [29]. There is some ambiguity regarding whether this requires public accessibility, depending upon the relevant national or regional context. Open spaces can be public assets, or privately owned, and proffer social benefits regardless of rights of access to the broader community. Urban open spaces include pocket parks, playgrounds, sports-fields, dog parks, landscaped parklands, botanical and other gardens, urban beaches and coastal reserves, 
local, regional and metropolitan parks, linear open space and trails, civic spaces, utilities and service areas, natural or semi-natural remnant urban forests, undeveloped areas, land use buffers, ridge lines and habitat corridors. Areas adjacent to but outside of cities' political boundaries are typically not included as urban open spaces; streets, malls, plazas, or city squares are also often excluded.

Some theorists regard urban open spaces as integral for the social, political and physical health of urban residents and communities. This is particularly true when appreciating the role of urban open spaces, such as pedestrian friendly neighbourhoods, in fostering and enabling interpersonal connections $[25,26,30]$. Political theorists like Habermas [22] describe an open space as a place where the functioning of democracy is strengthened as ideas are exchanged among diverse subcultural groups. This public ideal is closely associated with the 'contact hypothesis' which argues that socio-spatial contact between different class and ethnic groups cultivates a healthy, social, psychological and political development amongst urban citizens [23, 24, 27, 28]. Falling under the umbrella of urban open space, urban green space contributes to this notion of urban meeting spaces and is also linked with positive human health outcomes and positively achieving urban sustainability.

\section{Urban green space}

While urban green space can be seen to overlap with urban open space (and perhaps as a subset of the latter), it has some features which distinguish it from the general concept of urban open space [51]. These features are important here, given the paper's focus upon urban greening and advancing methodologies for assessing related community wellbeing benefits. Taylor and Hochulli [51] describe urban green space as "a vegetated variant of open space" and it is characterised by the creation of a biophysical living environment that operationalises biophilic urbanism principles. Urban open space does not necessarily involve substantive "greening" but can include open urban areas with few natural elements such as paved sports fields, concrete civic plazas, and public spaces around monuments. Their primary purpose and benefits may not be based on nature but on enhancing social interaction, recreation and health benefits, and cultural experiences. There will often be secondary "natural" elements such as open skies, views and air flows, but these may be indirect consequences of providing the open spaces. Arguably, urban green space may not even be "open" if it is densely populated with nature elements. Hence, it is important to conceptually distinguish urban open space and urban green space for the purposes of this analysis. The latter has very clear and strong relevance for assessing urban greening benefits.
The importance of urban green space has been recognised in urban design for more than four decades, since MacHarg [33] described the role and significance of urban green space in the built environment. The term is more limited in its geographic scale of implementation, with a focus mainly on specific intra-urban spatial interventions. It does not cover the full potential range of urban greening initiatives (for example, building scale elements) but covers an extensive range of land use types with nature integration benefits. Urban green space is defined as an integrated area comprising of natural, semi-natural, or artificial green, providing a myriad of benefits to various groups of people [31]. Jim and Chen [32] define urban green space as an open space in a city environment with deliberate (by design) or inherited (by default) vegetation cover.

Western towns and cities have traditionally incorporated urban green areas to promote social activities and for functional separation. The terrace-shaped gardens of the Renaissance and the landscaped gardens of the 18th and 19th centuries serve as examples of using urban green space for leisure and recreation. Urban green space is also recognised as a crucial component of a city's identity. Green areas are not only aesthetically pleasing but also historically, ecologically, and culturally assets of great significance for any city.

In recent years, many towns and cities have introduced new programmes based on ecological approaches to protect and manage nature in cities. With emphasis placed on sustainable development and quality of life in recent years, many policy makers and planners have started to clean up and replace under-utilised brownfield sites with green spaces such as parks, playgrounds, and greenways [34]. Emphasis is also placed on ensuring that urban residents have adequate exposure to nature; urban biodiversity is protected and maintained; air and noise pollution are reduced, and extreme weather events are mitigated to enhance residents' health, well-being and quality of life.

\section{Urban green infrastructure}

The term 'urban green infrastructure' (UGI) dates back to 1994, where it was initially coined in Florida in a report to the governor on land conservation strategies and was intended to capture the significant role of natural systems as crucial, if not more important, components of a city's grey infrastructure [52]. Grey infrastructure refers to the human-engineered infrastructure for water resources such as water and wastewater treatment plants, pipelines, and reservoirs. Grey infrastructure typically refers to components of a centralized approach to water management. While urban design inevitably considers the role of grey infrastructure, green infrastructure suggests that planning should also consider the role of 
natural systems and its contribution to community planning [36]. UGI hence differs from urban open space and urban green space as it emphasises comprehensive system analysis, networks and interconnections of urban nature. When the outcome is to enhance the functioning of society, in a full economic, social and environmental sense, UGI is consistent with urban greening goals and climate change adaptation.

UGI has more recently been defined as "an interconnected network of multifunctional green-spaces that are strategically planned and managed to provide a range of ecological, social, and economic benefits" [36]. CSIRO [38] provides a slightly different definition, where it defines urban green infrastructure as all the vegetation that provides environmental, economic and social benefits such as clean air and water, climate regulation, food provision, erosion control and places for recreation. UGI includes urban parks and reserves, wetlands and stream corridors, street trees and roadside verges, gardens and vegetable patches, bikeways and pedestrian trails, wall and rooftop gardens, orchards and farms, cemeteries and derelict land.

Several disciplines have explored the role of green infrastructure including planning, landscape architecture, forestry, conservation biology and even transportation. Within the field of landscape ecology and architecture, Hellmund et al. [44] discuss the greenways movement conserving green corridors, often along river streams - as critical connection habitats. Furthermore, they recognise the crucial ecological or ecosystem services provided by forest and wetland habitats, such as water filtration and air purification, which are essential to the healthy functioning of the built environment.

Evolving from incremental, ad hoc additions of green space in the built environment, green infrastructure pushes for interrelated systems which provide commodities and services essential to enable, sustain, and even enhance societal living conditions [42]. In terms of implementation, ideally green infrastructure planning takes place before development begins. This allows planners to strategically place green infrastructure in areas where they can reap maximum benefits from the ecological functioning of these natural systems. For instance, land can be designed effectively such that wildlife habitat is protected and restored, stormwater is collected and treated, and community health is enhanced [40]. Examples of green infrastructure in contemporary urban planning literature include green roofs, permeable vegetated surfaces, green alleys and streets, urban forests, public parks, community gardens and urban wetlands $([37,39,41])$.

\section{Biophilic urbanism}

Historically, the urban environment has been the most environmentally degraded of all human environments, where disconnection from nature has become routine and essentially standard. In theory, this does not have to occur. When considering integrating nature into a city's fabric, the purpose and approach is important. Contact with nature in the built environment is far more than simply inserting a recreational amenity or an aesthetic into a city. Rather it is recognising as McHarg notes, "the necessity of sustaining nature as a source of life, milieu, teacher, sanctum, challenge and, most of all, of rediscovering nature's corollary of the unknown in the self, the source of meaning" [53]. The term biophilia captures the essence and significance of our relationship with nature - humans possess an inherent tendency to affiliate with the natural world as a result of our evolution as a species $[47,53-55]$. The evolutionary logic of biophilia is: for more than 99 percent of our existence, we evolved surrounded by the natural world. Most of what we recognise as normal today from electronic media to large scale agriculture to skyscrapers only emerged in the last 5000 years and less. Our intellect, emotions and senses developed in interactive relation to natural not human-created forces [48].

Ulrich et al. [13] described the restorative influence of nature on human beings' well-being derived from the psycho-evolutionary theory. Following a stressor, this theory explains that exposure to nature creates a shift in feelings towards a more emotionally positive state, positive changes in activity in various physiological systems, and even moderately high levels of sustained attention. This theory further exemplifies that human beings are innately aesthetically attracted to natural content.

Extending the principle of biophilia and the psychoevolutionary theory to city design, biophilic urbanism proposes the incorporation of intentional natural design features across cities, neighbourhoods and buildings to offer daily exposure to natural systems. Biophilic urbanism understands that human beings are a part of the ecosystem and focuses how cities should be designed to protect each resident at the individual level. This suggests a holistic approach in the way cities are designed to create socially optimal outcomes. Cities with substantial and effectively integrated nature, provide a range of economic, environmental and related health and wellbeing benefits. Biophilic urbanism promotes infrastructure that are intended to and encourage immersion in urban nature, with an emphasis on the wellbeing benefits that come from human connectedness with nature.

The concept of biophilic urbanism presents a unique opportunity to create sustainable and liveable cities to promote well-being, placing the evolutionary significance of natural systems and processes at the core of city design $([45,46])$. A key aspect is the presumption that nature integration in cities increases wellbeing via many social and psychological dimensions as well as via purely physical functions. Hence, it is unique in the sense that 
there is an explicit goal of enhancing wellbeing based upon E. O. Wilson's psychological principle of biophilia [5].

In summary, biophilic urbanism represents the idea of integration of urban nature into cities and proffers a design principle to inform the intentional and functional use of natural or 'biophilic' elements, such as city and pocket parks, linear green space, and green roofs and walls in the built environment [7]. It is emerging as a field that explores relationships between wellbeing and urban spaces, where researchers are demonstrating that nature integration has both urban metabolism and strong socio-psychological effects $([46,56])$. Essentially, the goal of biophilic urbanism ameliorate the urban disconnect from nature, promoting the experience of nature and making it the core of everyday city life. Biophilic urbanism promotes the need for cities to encompass a vast array of ecological systems and human activities, encouraging a healthy relationship between the built environment and nature.

\section{Results}

\section{Biophilic services as an overarching term for evaluation}

The corpus of literature discussed above indicates an evolution in the perspective of nature in cities - from a focus upon more instrumental, practical, aesthetic benefits (i.e. separation of functions, externality reduction), to a more social, psycho-evolutionary focus. This evolution to more psychic or psychogenic aspects of the benefits of nature in cities is captured within the last of the described terms 'biophilic urbanism', which captures the functional, psychoevolutionary and even economic benefits of nature in cities. Except for 'biophilic urbanism', the range of initiatives and approaches covered in Table 1 do not adequately embody the deeper eco-psychological effects, and related social and economic impacts, that appear to result from direct human-nature connections in everyday urban life [57].

Biophilic urbanism explores and explains how nature can be integrated in a way that address a city's economic, environmental and social needs, through the integration of 'biophilic elements' that are directed towards the underlying assumptions and goals of biophilic urbanism [12]. While the term does not necessarily consider the full scope of social benefits and costs that can flow as cobenefits from the interventions directed towards this endgoal (for example, water and energy-savings), such impacts are also critical in accurately assessing the ideal extent and form of initiatives and programs to promote biophilia in cities.

To acknowledge and capture this more comprehensive nature of impacts, we use the term biophilic services in Table 2 below. Coined by el-Baghdadi and Desha [56], biophilic services are defined as "the benefits yielded from intentional interventions in the built environment, providing conditions and processes through which one or more biophilic elements yield direct or indirect, implicit or explicit, quantitative or qualitative enhanced wellbeing". In their study, el-Baghdadi and Desha discuss the functional and intentional role of biophilic urbanism as an urban planning concept and present the term biophilic services to also capture the full scope of economic and environmental impacts yielded from biophilic interventions - or 'biophilic elements' - in the built environment. This includes not only the socio-cultural, deeper psychological benefits but also the financial contributions and biophysical effects of implementing biophilic urbanism.

In the following paragraphs, we discuss the role of biophilic services to inform decision-making about the extent and form of future 'greening' programs and initiatives. Through developing an analytical framework for evaluating biophilic services as an extension of total economic value and environmental valuation approaches, we propose decision-making capabilities can be substantially enhanced for better expenditure of budgets.

\section{The role of biophilic services in decision making}

As discussed above, biophilic urbanism emphasises the multi-sensory, positive human experience of nature, going beyond the largely biological benefits associated with 'green cities', 'urban green space' and 'green infrastructure'. In addition to using the functional and instrumental capacities or services of natural systems, there is a significant opportunity to document the potential benefits and means of understanding this 'affinity' with nature, which can then guide the identification of relevant valuation techniques $[58,59]$.

Table 2 and the following paragraphs present the results of a detailed analysis and systematic classification of biophilic urbanism and biophilic services, where we have identified primary social 'wellbeing' benefits and other urban greening environmental co-benefits. The nine element columns have been derived (with minor modification) from el Baghdadi and Desha [56] and Reeve [8]. The biophilic urbanism elements are sorted, from left to right, in increasing spatial resolution - from building scale, to neighbourhood scale to city scale. The six major impact classes and 38 sub-categories listed as rows in Table 2 have been drawn from a diverse and comprehensive survey of existing research on urban greening approaches. The effects were then condensed into a convenient scheme that covered, and was consistent with, the ecosystem services functional groupings and categories of the Millennium Ecosystem Assessment report [60]. Lobo [61] and de Groot et al. [62] also provided key guidance to this classification process and structure.

The resultant matrix highlights the main types of social and economic impacts associated with each biophilic 
Table 2 The community benefits and costs of urban greening (with a focus upon biophilic urbanism elements)

\begin{tabular}{|c|c|c|c|c|c|c|c|c|c|}
\hline \multirow[t]{3}{*}{$\begin{array}{l}\text { Impacts } \\
\text { (Benefits '+' and Costs '-' as indicated) }\end{array}$} & \multicolumn{3}{|c|}{ Building Scale Elements } & \multicolumn{3}{|c|}{$\begin{array}{l}\text { Neighbourhood Scale } \\
\text { Elements }\end{array}$} & \multicolumn{3}{|c|}{ City Scale Elements } \\
\hline & 1.1 & 1.2 & 1.3 & 2.1 & 2.2 & 2.3 & 3.1 & 3.2 & 3.3 \\
\hline & $\begin{array}{l}\overline{\text { Indoor \& }} \\
\text { atrium } \\
\text { vegetation }\end{array}$ & $\begin{array}{l}\overline{\text { Green }} \\
\text { Roofs }\end{array}$ & $\begin{array}{l}\text { Green } \\
\text { Walls } \\
\text { (Internal \& } \\
\text { External) }\end{array}$ & $\begin{array}{l}\text { Green } \\
\text { verges, } \\
\text { green } \\
\text { streets, } \\
\text { greenways, } \\
\text { street trees, } \\
\text { walk-ways }\end{array}$ & $\begin{array}{l}\text { Green } \\
\text { islands, } \\
\text { pocket } \\
\text { parks, } \\
\text { vacant } \\
\text { land }\end{array}$ & $\begin{array}{l}\text { Other } \\
\text { outdoor } \\
\text { lot level } \\
\text { lawns, } \\
\text { gardens, } \\
\text { trees }\end{array}$ & $\begin{array}{l}\text { Green } \\
\text { corridors, } \\
\text { buffer } \\
\text { zones; } \\
\text { public } \\
\text { areas }\end{array}$ & $\begin{array}{l}\text { Urban } \\
\text { gardens \& } \\
\text { farming }\end{array}$ & $\begin{array}{l}\text { Green } \\
\text { Waterways } \\
\& \text { water } \\
\text { sensitive } \\
\text { design }\end{array}$ \\
\hline
\end{tabular}

\section{ECONOMIC}

- Tourism revenues

- Water availability, security, groundwater

- Soil and other natural resource demands

- Recreational/discretionary time availability

- Property values, retail, other related revenue

- Worker productivity and returns

- Resources for health care

- Energy demands, productivity security

- Food production and security

- Water demands, productivity,

- Damage costs to infrastructure

- Pests and disease

\section{ECOSPHERE HEALTH}

- Broad-scale ecosystem vitality

- Biological and genetic diversity

- Broad-scale pollution management functions

- Pollination, growth, health of plant species

INDIVIDUAL PHYSICAL AND MENTAL HEALTH (AESTHETIC, SPIRITUAL, ECO-PSYCHOLOGICAL)

- Pollution-related mitigation

- Wellbeing from immersion in nature

- Other aesthetic, spiritual, inspirational value

- Mood and well-being

- Exercise-related effects

- |l-health recovery time

URBAN QUALITY OF LIFE, ENVIRONMENTAL QUALITY

- Microclimate changes

- Noise pollution abatement

- Waste/ pollution detox, filtering, composting

- Other effects on urban environments

- Enhanced soils, urban ecosystem vitality

- Water supply quantity, security, quality

- Health, safety, resource savings and welfare

\section{URBAN SOCIAL AND CULTURAL CAPITAL}

- Nature-based cultural identification

- Sociocultural capital, knowledge economies
$+$

++

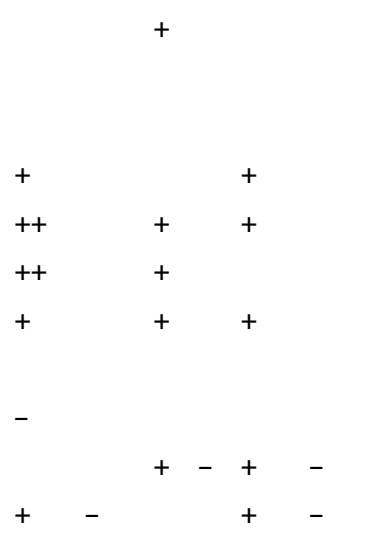

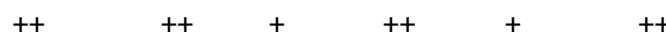

$+$

$+$

$+$

$+$

\section{$+\quad++$}

$+$

$++$

$++$

$+\quad++$

$++$

$++$

$+$

$+$

$++$

$++$

$+$

$+$

$+$

$+$

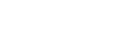

$\begin{array}{lllllll}+ & + & & & + & & + \\ & + & + & & ++ & \end{array}$

$+$
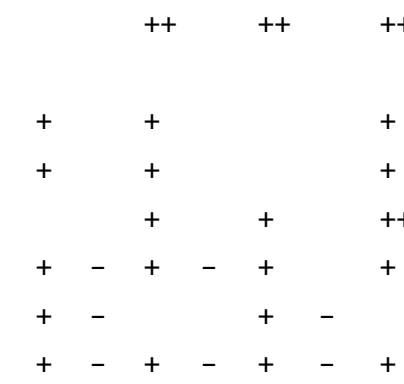

.

$+\quad+\quad++$

$+\quad++$

$+\quad++$

$+$

++
++
++
++

$\begin{array}{lll}++ & + & ++ \\ ++ & + & ++ \\ ++ & + & ++ \\ ++ & + & ++\end{array}$

$\begin{array}{ccc}++ & + & + \\ ++ & + & + \\ ++ & + & + \\ + & & + \\ + & \end{array}$

+
++
++
++
+
+

$\begin{array}{ll}+ & + \\ + & + \\ + & \\ + & \end{array}$

$\begin{array}{ccr}+ & + & + \\ + & ++ & + \\ ++ & ++ & + \\ + & ++ & + \\ ++ & ++ & + \\ & + & +\end{array}$

$\begin{array}{cccc}+ & ++ & ++ & ++ \\ + & + & + & ++ \\ ++ & + & + & + \\ + & + & + & + \\ & + & & + \\ & & & +\end{array}$

$\begin{array}{ccccc}+ & ++ & + & + & + \\ + & ++ & + & + & \\ + & ++ & ++ & ++ & ++ \\ ++ & ++ & + & ++ & + \\ + & ++ & ++ & ++ & ++ \\ + & ++ & + & ++ & ++ \\ + & + & + & + & ++ \\ & & & & \\ ++ & ++ & ++ & ++ & ++ \\ ++ & ++ & ++ & ++ & ++\end{array}$


Table 2 The community benefits and costs of urban greening (with a focus upon biophilic urbanism elements) (Continued)

\begin{tabular}{|c|c|c|c|c|c|c|c|c|c|}
\hline \multirow[t]{3}{*}{$\begin{array}{l}\text { Impacts } \\
\text { (Benefits '+' and Costs '-' as indicated) }\end{array}$} & \multicolumn{3}{|c|}{ Building Scale Elements } & \multicolumn{3}{|c|}{$\begin{array}{l}\text { Neighbourhood Scale } \\
\text { Elements }\end{array}$} & \multicolumn{3}{|c|}{ City Scale Elements } \\
\hline & 1.1 & 1.2 & 1.3 & 2.1 & 2.2 & 2.3 & 3.1 & 3.2 & 3.3 \\
\hline & $\begin{array}{l}\text { Indoor \& } \\
\text { atrium } \\
\text { vegetation }\end{array}$ & $\begin{array}{l}\text { Green } \\
\text { Roofs }\end{array}$ & $\begin{array}{l}\text { Green } \\
\text { Walls } \\
\text { (Internal \& } \\
\text { External) }\end{array}$ & $\begin{array}{l}\text { Green } \\
\text { verges, } \\
\text { green } \\
\text { streets, } \\
\text { greenways, } \\
\text { street trees, } \\
\text { walk-ways }\end{array}$ & $\begin{array}{l}\text { Green } \\
\text { islands, } \\
\text { pocket } \\
\text { parks, } \\
\text { vacant } \\
\text { land }\end{array}$ & $\begin{array}{l}\text { Other } \\
\text { outdoor } \\
\text { lot level } \\
\text { lawns, } \\
\text { gardens, } \\
\text { trees }\end{array}$ & $\begin{array}{l}\text { Green } \\
\text { corridors, } \\
\text { buffer } \\
\text { zones; } \\
\text { public } \\
\text { areas }\end{array}$ & $\begin{array}{l}\text { Urban } \\
\text { gardens \& } \\
\text { farming }\end{array}$ & $\begin{array}{l}\text { Green } \\
\text { Waterways } \\
\text { \& water } \\
\text { sensitive } \\
\text { design }\end{array}$ \\
\hline - Social capital-building, interaction, trust & & & & + & ++ & + & + & ++ & + \\
\hline - Spiritual, cultural, historical and heritage & & & & + & + & + & ++ & + & + \\
\hline - Ornamental, culturally significant resources & + & + & + & + & + & + & ++ & + & + \\
\hline \multicolumn{10}{|l|}{ URBAN VITALITY AND EXPERIENCE } \\
\hline - Urban vitality, environment, experience & ++ & + & + & ++ & ++ & + & ++ & + & ++ \\
\hline - Associated economic quality of life benefits & ++ & + & + & ++ & ++ & + & ++ & + & ++ \\
\hline - Efficiency, speed, access - transport networks & & & & + & + & + & ++ & + & + \\
\hline - Traffic calming, incidences & & & & + & + & + & ++ & + & + \\
\hline
\end{tabular}

urbanism element (as indicated by the '++' and '+' symbols), and how the impacts vary across different elements.

The 'impacts' rows of Table 2 have been analysed in accordance with the definition of 'impacts' adopted in the drivers, pressures, state, impact and response (DPSIR) environmental systems analysis framework [63]. DPSIR helps provide standardised terminology and consistency in environmental analysis and has been widely adopted in many major national and international environmental management agencies. In the DPSIR framework, impacts are restricted to social and economic effects upon humans because of environmental state changes. Changes that are solely in the environmental realm, devoid or prior to touching the human realm, are classified as 'state' (S) changes in the DPSIR approach. However, we do include some environmental state changes in Table 2 (notably for 'Ecological health') given the holistic nature of these effects. To attempt to value these effects, when possible, it would be necessary to first assess their actual social and economic effects (for example, economic production and health cost impacts of the reduced pollination or genetic diversity).

Table 2 reveals the main social and economic direct and indirect impacts associated with the specific biophilic urbanism elements and the general nature of the impacts overall. Most of the social and economic dimensions are affected across all geographic scales. However, there is a general trend of increasing impact in latter impact categories as the geographic scale of element implementation increases. The latter impact categories include urban quality of life, environmental quality, social and cultural capital, broader ecosphere health, urban functionality, and urban vitality and experience.
Major building scale elements have impacts spanning health, worker productivity, and indoor environmental quality (especially for indoor elements). Green roofs and walls are closely linked to microclimate and economic and energy savings. At the neighbourhood scale, the more extensive elements ('Other Outdoor') have substantive benefits for physical and mental health, aesthetic and eco-psychological wellbeing, and economic resource savings. As expected, the city-scale initiatives have similar impacts to extensive neighbourhood scale though urban gardens and farming can be seen to link more closely to physical and mental health; aesthetic, spiritual and eco-psychological welfare; and some economic resource use effects. Alternately, green corridors, interurban buffer zones, and public acquisition of natural land areas, have more effect on urban quality of life, environmental quality, social and cultural capital, broader ecosphere health, urban functionality, and urban vitality and experience.

\section{Opportunities and challenges for evaluation techniques}

To assess social benefits and costs, the environmental economic logic usually flows from: 1) the identification and biophysical (or related) measurement of state changes and impacts; to 2) classification of these effects within schemes such as the MEA's ecosystem service and the total economic value (TEV) scheme; and finally to 3) the appropriate and selective application of environmental valuation or other assessment techniques. This can be followed by the compilation of the assessments from step (3) and recommendation of policy strategies via decision-making frameworks such as social benefitcost analysis or multi-criteria assessment. 
Aligning the social benefits and costs of elements with a typology such as that presented in the TEV scheme greatly facilitates the capacity to utilise appropriate techniques for economically assessing the consequences of pursuing biophilic urbanism. The concept of total economic value is a classification scheme intended to cover and categorise all the possible benefits or positive values of a natural resource or system natural resources to society (including long-term and global society) and source, sink, life support and amenity values $[64,65]$.

The label 'total' economic value is somewhat misleading as the aim of TEV is the comprehensive identification of the full range of benefits (and part valuation of suitable impacts) rather than the calculation of some overall monetary value. Total economic value and externality analysis and measurement is of relevance to biophilic urbanism given the plethora of indirect, often its supra-market impacts. Most of the biophilic urbanism initiative impacts can be framed in terms of the gains or losses in TEVs, but there is a need for an extended version of the TEV scheme which adequately covers social and shared value and cultural values.

It is also important to note that implementing elements into the urban context will have many private and external costs. Some of these impacts have been denoted in Table 2 (with a "- "sign). In addition to the direct private economic costs of implementing biophilic urbanism (BU) can have many additional costs. They comprise a series of (often inter-related) environmental, social, economic and other mixed impacts such as those associated with urban metabolism flows, urban density and sprawl, accessibility and vegetation litter. Possible biophilic urbanism initiative community costs mainly take the form of externalities and secondary economic effects. Building on the work of Matthews, Lo and Byrne [35] and Roy, Byrne and Pickering [64], Table 3 summarises key potential negative effects of $\mathrm{BU}$ that must be carefully considered within the 'trade-off' logic of economic analysis to assess the net community benefits of such initiatives within the context of limited resources.

In addition there are a range of other and mixed conditional impacts associated with the consequences of biophilic urbanism initiatives upon urban density and form. The cost/benefit nature and magnitude of these impacts will depend upon the existing compactness and biophilic urbanism related implications for urban form and density. It is possible to have high population density but an abundance of open space. Urban sprawl can mean private yards (arguably a significant element) but limit green access. Sprawl and housing/ transport distribution also, of course, have a major influence upon transportation needs, infrastructure and energy. These factors will affect competition for space, housing and industry costs. The World Cities Report [67], p159 reports that the "loss of density in urban areas over the last two decades demonstrates that demographic and spatial expansion go hand in hand. Less dense cities bring higher infrastructure costs, worsen mobility, and destroy agricultural land". If biophilic urbanism initiatives decrease compactness, these effects and urban material, energy and waste consequences, may well be adverse.

Hence, BU initiatives may lead to increased urban metabolism as reflected in measures such as greenhouse gas emissions, water footprints, other material, energy and waste flows and demands from the hinterland and beyond. They may also lead to increased vegetation litter and associated costs, possible increased distraction and reduced direct economic productivity due to the attractiveness of and more time appreciating or immersed in nature. Natural areas can also increase hazards from extreme weather events, including for example tree-fall.

\section{Discussion}

Challenges to improving the integration of 'biophilic services'

Effective urban planning and environmental management must consider the full range of social benefits and

Table 3 Potential community (private and external) costs of biophilic urbanism initiatives

\begin{tabular}{ll}
\hline Impact Type & Considerations \\
\hline Environmental & - Biophilic urbanism changes may promote human-wildlife conflict; introduce weeds and pest species; lead to \\
& insect infestation; or lower groundwater \\
& - (leading to social \& economic costs) \\
- Speed eco-gentrification and social dislocation; lead to health impacts such as allergies (e.g. asthma), disease, & insect bites \\
- Change the "character" of an area. & - Increase risk and fear of crime and animal attacks, general 'biophobia' \\
& - Some cultural groups may not have the same view of green space and prefer alternative land and resource use. \\
& - Neighbourhood and broader scale elements may reduce accessibility, separate social groups and stifle \\
& interaction (including by urban sprawl access issues) [66]. \\
& - Increase property values and reduce affordability. \\
- Increase heating expenses, water, roots damage infrastructure, increase maintenance costs, insurance costs. & - Reduced visibility (increasing accident risk and related problems) and increased risk and incidence of injury \\
Economic & related to vegetation. \\
\hline
\end{tabular}


costs of development options. Improved community wellbeing in the twenty-first Century will require strategic evaluation that prioritises the socio-psychological aspects of urban greening that are so well captured in the concept of biophilic urbanism. This comprehensive assessment approach should not be just based on a limited range of functional and discrete operational objectives but take a broad design, and integrated metabolism or sustainability analysis, perspective. Biophilic urbanism helps by highlighting and setting the basis to assess, measure and quantify the potential benefits of less physical connections between humans and nature. Hence, a transdisciplinary approach is well-suited, if not essential, with vigorous cross-disciplinary research spanning geography, economics, sociology, psychology, planning, engineering, physics and many other scientific fields.

\section{Cogent research questions for biophilic urbanism and urban greening}

Advances in implementing biophilic urbanism, and urban greening in general, will proceed with the iterative development and resolution of several major research questions. As pursued in this paper, the identification and estimation of the main private and external costs and benefits of urban greening initiatives will be vital for justifying and guiding such strategies. This article has proposed an explicit emphasis upon biophilic aspects and their ecopsychological effects. These effects have not been well covered most other urban greening approaches - even those with a marked environmental or sustainability focus.

Closely related to this general issue, a key research focus is the identification of the main likely impacts of biophilic urbanism and other urban greening initiatives on the urban metabolism in terms of material, energy and waste resource flows. Then there are the primary contextual factors that will influence the likelihood of net community gains from biophilic urbanism initiatives, including for example, existing urban infrastructure and pattern of development, density, open space levels, land costs, transport flows and existing traffic issues, and the specific cultural affinity with nature.

A major issue to assess are the constraints upon effective biophilic urbanism implementation. Many of these would link to the contextual factors affecting potential community gains noted in the previous paragraph. A detailed list of possible constraints is presented in the following paragraphs. There is clear gap in existing research exploring the social costs of biophilic urban initiatives, rather than just the benefits. Finally, a key research goal drawing upon this range of questions would involve the identification of optimal levels of urban greening (and embodied biophilic urbanism) for community wellbeing [66] and how to effectively facilitate access to, use and benefits if these initiatives are implemented.

\section{Constraints to implementation}

In identifying the wide variety and extensive suit of benefits likely to be derived from biophilic urbanism and related initiatives, there is a need to carefully balance these potential social and economic impact costs to the community with their biophysical, socio-political and economic viability, and other constraints to successful implementation at building, neighbourhood and city scales.

There are many potential constraints upon urban greening as a means of implementing biophilic urbanism. They are also closely associated with the main contextual influences that affect the likely net community gains from such measures. Extending upon related work by Matthews et al. [35] and Byrne and Yang [37], these challenges are summarised in Table 4.

\section{Conclusions}

In this paper, we have explored the use and benefits of several approaches to integrating nature within cities. We have presented an operational planning term 'biophilic services' that covers the full range of social benefits and costs that come with initiatives that are used to promote biophilic urbanism. We conclude that biophilic urbanism can play a valuable integrating role in the urban greening agenda, bringing together related but different concepts spanning green space and infrastructure. There is a need for a robust methodological framework for improving the evaluation of urban greening efforts, in the form of 'net community benefits'.

We considered the range of social benefits and costs arising from biophilic urbanism including a systematic classification of impacts of biophilic urbanism elements and their links to the MEA's 2010 report classification of ecosystem services, and the total economic value (TEV) conceptual framework for assessing the benefits of natural resources to humans. TEV has strengths in relation to the systematic and comprehensive nature of the approach, where benefits can be at least partly monetised and made more readily accountable to reporting measures in relation to ad hoc alternative assessment approaches. However, we acknowledged the limitations of TEV and environmental valuation approaches to assess net community benefits of urban greening.

TEV has a role but tends to be too restricted to material and energy flow aspects - it needs to include significant socio-cultural and psychological interconnectedness aspects. While a useful part of the assessment process in establishing 'business case' aspects, TEV needs to be complemented with deliberative and participative assessment of social/shared values. Elaborating on this environmental valuation potential is a future goal for the authors. Given the identification of the full range of social benefits and costs in this paper, future research will build on Table 2 to analyse the types of TEV categories most affected by biophilic urbanism initiatives to 
Table 4 Key constraints to implementation

\begin{tabular}{|c|c|c|}
\hline Aspect & Constraint & Details and examples \\
\hline \multirow[t]{2}{*}{ Biophysical Capability } & $\begin{array}{l}\text { 1. The biophysical character of built } \\
\text { environment }\end{array}$ & $\begin{array}{l}\text { Considering available space, urban space limits; relative demand levels for } \\
\text { housing; urban morphology, site contamination, physical geographic and } \\
\text { geological features, vegetation characteristics, climate; water conditions and } \\
\text { systems }\end{array}$ \\
\hline & 2. Existing urban form & $\begin{array}{l}\text { With strong constraints likely in high density, high population, rapid } \\
\text { urbanisation and low open space cities in low and middle-income nations }\end{array}$ \\
\hline \multirow[t]{4}{*}{$\begin{array}{l}\text { Socio-Political and } \\
\text { Economic Feasibility }\end{array}$} & $\begin{array}{l}\text { 3. Maintenance and other immediate } \\
\text { economic costs }\end{array}$ & As listed in section 3.2 \\
\hline & $\begin{array}{l}\text { 4. Planning systems - complexity } \\
\text { and uncertainty }\end{array}$ & $\begin{array}{l}\text { Planning priorities; institutional inertia; too few planners; uncertainty; rigid } \\
\text { traditional planning approaches and knowledge; lack of experience with } \\
\text { urban greening; concerns over significant change (e.g. roots encroachment, } \\
\text { structural integrity, water damage) }\end{array}$ \\
\hline & $\begin{array}{l}\text { 5. Other institutional frameworks and } \\
\text { decision-making and governance } \\
\text { structures - }\end{array}$ & $\begin{array}{l}\text { Including economic; and socio-political factors such as fiscal constraints, } \\
\text { governance systems e.g. government role and power vis-a-vis corporate and } \\
\text { other private sector actors, public involvement in decision-making and } \\
\text { planning. The long-term nature of many urban greening benefits (or costs } \\
\text { prevented) conflicts with many aspects of politico-economic systems and } \\
\text { short-term economic performance cycles. }\end{array}$ \\
\hline & $\begin{array}{l}\text { 6. Perceptions and values of residents - } \\
\text { biophobia involvement }\end{array}$ & $\begin{array}{l}\text { Disconnect or lack of familiarity with, and hence fear of, nature, partially due } \\
\text { to socialisation into artificial, controlled environments; cultural perceptions of } \\
\text { nature; economic history and attitudes towards public market forces ideology } \\
\text { influence }\end{array}$ \\
\hline \multirow[t]{3}{*}{$\begin{array}{l}\text { Miscellaneous } \\
\text { Constraints }\end{array}$} & $\begin{array}{l}\text { 7. Ambiguity about concepts and } \\
\text { approaches }\end{array}$ & $\begin{array}{l}\text { Open space, urban green space, and green infrastructure. Addressing this } \\
\text { issue has been one of the major aims of this paper. Uncertainty regarding the } \\
\text { "green-ness" or biophilic services associated with some urban features e.g. } \\
\text { lawns. }\end{array}$ \\
\hline & 8. Lack of data about net benefits & $\begin{array}{l}\text { Uncertainty, complexity of relevant dose-response relations (and about } \\
\text { external changes e.g. climate change); economic valuation limits; "agency of } \\
\text { nature" [35] }\end{array}$ \\
\hline & 9. Path dependence & $\begin{array}{l}\text { Spatial planning and urban form changes as politically unpalatable and } \\
\text { expensive - Loss of short-term profit, capital gains, lost revenue and tax, } \\
\text { infrastructure cost); property rights constraints }\end{array}$ \\
\hline
\end{tabular}

recommend and position the most relevant environmental valuation techniques that may apply for its various impacts.

The paper has also reviewed some of the major research questions that need to be the focus of ongoing research to effectively implement urban greening initiatives that fully realise the potential of biophilic urbanism. We have considered, in some detail, the offsetting social costs of urban greening and the range of challenges to its implementation.

The analysis presented also helps to develop the potential for including the more intangible socio-psychological dimensions and benefits of urban greening initiatives in decision-making processes. These may include ethical and cultural considerations and spiritual appreciation - aspects that are often assumed but not readily assessed for informed decision-making. The synthesis of urban greening efforts completed here provides a useful summary for planning and decision-making, while the assessment of social benefits and costs of implementing key urban greening initiatives facilitates project evaluation and better balancing in urban design for net community wellbeing. Subsequent research will identify the appropriate use and limits of specific environmental valuation techniques for more effectively assessing the strategic integration of nature within cities.

\section{Methods}

This study builds upon a research study which presented an extension to the theory of ecosystem services in the form of 'biophilic services' and explained how this plays an influential role in informing decisions regarding whether to incorporate biophilic urbanism in city environments [56]. The study also presented a decisionmaking flow which captures underlying logic that appears to be informing biophilic urbanism.

The research completed here extends upon the 'biophilic services' component of the doctoral research study to set the essential context and framework required to guide a consistent and systematic approach to assessing the net community benefits of potential measures for promoting biophilic urbanism and other bases for integrating nature within urban areas. This study proposes an explicit emphasis on biophilic urbanism and its elements, with more detailed analysis of impacts, using the Millennium Ecosystem Assessment (MEA) [60] 
ecosystem services scheme, and related concepts from the "total economic Value (TEV) framework.

The methodology deployed in this paper is based on a review, compilation and classification of an extensive range of existing relevant theory and studies related to the community benefits (and costs) of any initiatives related to urban greening. These impacts are systematically identified in terms of the MEA 2005 ecosystem service scheme and are presented in a form that will facilitate further economic valuation approaches in accordance with the total economic valuation framework (in research currently underway by the authors).

The major output of this paper is the detailed analysis and compilation of the main social and economic, direct and indirect, impacts associated with nine specific biophilic urbanism elements. These elements are based largely on geographic scales of implementation. The analysis and systematic classification of biophilic urbanism and biophilic services, where we have identified primary social 'wellbeing' benefits and other urban greening environmental co-benefits. The nine element columns have been derived (with minor modification) from el Baghdadi and Desha [50] and Reeve [56]. The biophilic urbanism elements are sorted, from left to right, in increasing spatial resolution - from building scale, to neighbourhood scale to city scale. The six major impact classes and 38 sub-categories listed as rows in Table 2 have been drawn from a diverse and comprehensive survey of existing research on urban greening approaches. The effects were then condensed into a convenient scheme that covered, and was consistent with, the ecosystem services functional groupings and categories of the Millennium Ecosystem Assessment report [60]. Lobo [61] and de Groot et al. [62] also provided key guidance to this classification process and structure.

The resultant matrix highlights the main types of social and economic impacts associated with each biophilic urbanism element (as indicated by the ' ++ ' and ' + ' symbols), and how the impacts vary across different elements.

The paper also includes three other sets of results useful in advancing the conceptual and methodological development foci of the study. First, the analysis presents (in Table 1) the results of a detailed literature review into key vocabulary, in order to distinguish and relate the range of operational terms for initiatives and changes that involve embedding nature within urban areas. The major characteristics of these various approaches are presented noting that the concepts often overlap and vary between researchers and disciplinary specialisations. Indeed, many are often used interchangeably despite ostensible differences. This information has also been gleaned from an extensive array of existing relevant conceptual and empirical work on urban greening (and especially biophilic urbanism).
This is also true of the identification and classification of potential community (private and external) costs of biophilic urbanism initiatives and the constraints facing its implementation in Tables 3 and 4. More details on the sources and approaches for these analyses are provided within the relevant sections.

\section{Abbreviations \\ TEV: Total Economic Value; UGI: Urban green infrastructure; DPSIR: Drivers, Pressures, State, Impact, Response model}

\section{Acknowledgements}

We acknowledge the support of the QUT Academic Language and Learning Service, in particular Karyn Gonano, in reviewing the academic writing of this article.

\section{Authors' contributions}

Omniya El Baghdadi undertook the literature review, analysis and interpretation of Table 2. Peter Daniels contributed to Table 2, the discussion and conclusions. Cheryl Desha contributed to the abstract, introduction, conclusions and a structural edit of the paper. Tony Matthews assisted with conceptualisation, paper aims and structure, as well as coordination and management of revisions. The authors read and approved the final manuscript.

\section{Authors' information}

Dr. Peter Daniels: Peter Daniels is an environmental and ecological economist at the School of Environment and Science at Griffith University (Gold Coast, Australia). He has an interdisciplinary undergraduate background in environmental science and has postgraduate qualifications in human geography (MA) and economics (PhD). His major research orientation is the relatively new trans-discipline of ecological economics with its emphasis on the biophysical consequences of economic activities and systems for environmental, economic and social sustainability.

Dr. Omniya El Baghdadi: Dr. el-Baghdadi is an Adjunct Industry Fellow with the Cities Research Institute, Griffith University, and a sustainable development specialist who is highly motivated to engage within a multidisciplinary context to find holistic and transformational solutions to counteract negative implications in the built environment. She specialises in pursuing new business opportunities, developing innovative project ideas, setting strategic goals to reach overall objectives, and completing projects even in difficult circumstances and incredibly tight timeframes, developing technical studies relating to sustainable development in the built environment, and building capacity through holistic community yoga programs and charitable service projects aimed at empowering communities.

Associate Professor Cheryl Desha: Cheryl Desha is an Associate Professor and Engagement Director (Industry) in the School of Engineering and Built Environment, Griffith University Brisbane, Australia. She is responsible for designing and delivering an unprecedented 'twenty-first Century' civil engineering curriculum and has been working to build capacity for sustainable development. She has co-authored more than 119 publications including 7 books, 2 of which have been listed in the top 40 publications by the Cambridge Institute for Sustainability Leadership.

Dr. Tony Matthews: Tony Matthews is a Senior Lecturer in Urban and Environmental Planning, based in the School of Environment and Science at Griffith University. He has a strong track record in research, teaching and practice and is widely published and cited in international planning literature aimed at scholars, students and practitioners. His research interests include: the interplay between planning and environmental management; climate change adaptation; green infrastructure; community-led engagement in planning processes, place-making; policy creation; resource management; and urban consolidation.

\section{Funding}

Not applicable.

Availability of data and materials Not applicable. 


\section{Ethics approval and consent to participate}

Not applicable.

\section{Consent for publication \\ Not applicable.}

\section{Competing interests}

The authors declare that they have no competing interests.

\section{Author details}

'School of Environment and Science/ Environmental Futures Centre, Griffith University, 170 Kessels Road, Nathan, QLD 4111, Australia. ${ }^{2}$ Cities Research Institute, Griffith University, 170 Kessels Road, Nathan, QLD 4111, Australia. ${ }^{3}$ Cities Research Institute, Griffith University, 170 Kessels Road, Nathan, QLD 4111, Australia. ${ }^{4}$ School of Environment and Science/Cities Research Institute, Griffith University, 170 Kessels Road, Nathan, QLD 4111, Australia.

\section{Received: 8 November 2018 Accepted: 7 May 2020}

\section{Published online: 20 August 2020}

\section{References}

1. United Nations, Department of Economic and Social Affairs, Population Division. World urbanization prospects: the 2014 revision, highlights. 2014.

2. Dobbs R, Smit S, Remes J, Manyika J, Roxburgh C, Restrepo A. Urban world: mapping the economic power of cities: McKinsey Global Institute; 2011.

3. McHarg I. Design with nature. Garden City: American Museum of Natural History; 1969.

4. Louv R. Last child in the woods: saving our children from nature-deficit disorder. Chapel Hill: Algonquin Books of Chapel Hill; 2005.

5. Wilson EO. Biophilia. Cambridge: Cambridge University Press; 1984.

6. Kellert S, Heerwagen J, Mador M. Biophilic design: The theory, science and practice of bringing buildings to life. Hoboken: Wiley; 2013.

7. Beatley T. Green urbanism: Learning from European Cities. Washington DC Island Press, 2009; 2000.

8. Reeve A, Desha C, Hargreaves D, Hargroves K. Biophilic urbanism: contributions to holistic urban greening for urban renewal. Smart Sustainable Built Environ. 2015:4(2):215-33.

9. De Ridder KD, Adame V, Banuelos A, Brused M, Burgend M, Damsgaarde O, et al. An integrated methodology to assess the benefits of urban green space. Sci Total Environ. 2004;334-335:489-97.

10. Zhou X, Rana MP. Social benefits of urban green space: A conceptual framework of valuation and accessibility measurements. Manag Environ Qual Int J. 2012;23(2):173-89.

11. Brunner PH. Reshaping urban metabolism. J Ind Ecol. 2007:11(2):11-3.

12. Ulrich RS. Chapter 3: Biophilia, Biophobia, and Natural Landscapes. In: Kellert SR, Wilson EO, editors. The Biophilia Hypothesis. Washington: Island Press; 1993. p. 73-137.

13. Ulrich RS, Simons RF, Losito BD, Fiorito E, Miles MA, Zelson M. Stress recovery during exposure to natural and urban environments. J Environ Psychol. 1991;11(3):201-30.

14. Kellert SR, Wilson EO. Chapter 2: The Biological Basis for Human Values of Nature. In: Kellert SR, Wilson EO, editors. The Biophilia Hypothesis. Washington: Island Press; 1993. p. 42-69.

15. Niemelä J. Ecology and urban planning. Biodivers Conserv. 1999;8(1):119-31.

16. Zhou N, Williams C. An international review of Eco-City theory, indicators, and case studies; 2013

17. Campbell S. Green cities, growing cities, just cities? Urban planning and the contradictions of sustainable development. J Am Plann Assoc. 1996;62(3): 296-312.

18. Lewis E. Green City development tool kit. Manila: Asian Development Bank; 2015 .

19. Roseland M. Dimensions of the eco-city. Cities. 1997;14(4):197-202.

20. Van Dijk P. Beijing and Rotterdam eco-cities? Using 100 criteria for a classification of ecological cities. Delft: Paper presented at the Knowledge Collaboration \& Learning for Sustainable Innovation ERSCP-EMSU conference, October 25-29; 2010.

21. UNEP. Towards a green economy: pathways to sustainable development and poverty eradication. A synthesis for policy makers. 2011.

22. Habermas J. The structural transformation of the public sphere [translated by T. burger and F. Lawrence, 1989]. Cambridge: MIT Press; 1962

23. Hajer M, Reijndorp A. In search of new public domain. Rotterdam: NAl; 2001.
24. Ihlanfeldt K, Scafidi B. The neighborhood contact hypothesis. Urban Stud. 2002;39:619-41.

25. Jacobs J. The death and life of great American cities. New York: Random House; 1961.

26. Tibbalds F. Making people friendly towns: improving the public environments in towns and cities. Harlow: Longman; 1992

27. Sennett R. The uses of disorder. New York: Vintage; 1971.

28. Sennett R. The conscience of the eye: the design and social life of cities. New York: Knopf; 1990

29. Stanley B, Stark B, Johnston K, Smith M. Urban Open Spaces in Historical Perspective: A Transdisciplinary Typology and Analysis. Urban Geography. 2012;33(8):1089-117.

30. Whyte WH. The social life of small urban spaces. Washington, DC: The Conservation Foundation; 1980.

31. Tzoulas K, Korpela K, Venn S, Yli-Pelkonen V, Kaz'mierczak A, Niemela J, James P. Promoting ecosystem and human health in urban areas using green infrastructure: A literature review. Landsc Urban Plan. 2007:81(3):167-78.

32. Jim CY, Chen WY. Recreation-amenity use and contingent valuation of urban green space in Guangzhou, China. Landsc Urban Plan. 2006;75(1-2):81-96.

33. MacHarg IL. Design with nature. New York: Doubleday; 1971.

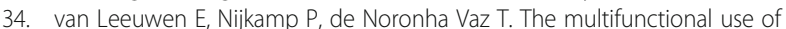
urban greenspace. Int J Agric Sustain. 2010;8(1-2):20-5.

35. Matthews $T$, Lo AY, Byrne JA. Reconceptualizing green infrastructure for climate change adaptation: barriers to adoption and drivers for uptake by spatial planners. Landsc Urban Plan. 2015;138:155-63.

36. Benedict MA, McMahon ET. Green infrastructure: linking landscapes and communities. Washington, D.C.: Island Press; 2006

37. Byrne J, Yang J. Can urban greenspace combat climate change? Towards a subtropical cities research agenda. Australian Planner. 2009;46:36-43.

38. CSIRO. Establishing a National Agenda for urban green infrastructure. 2015. http:// www.csiro.au/en/Research/LWF/Areas/Resilient-cities-21C/Green-infrastructure.

39. Douglas I. The role of green infrastructure in adapting cities to climate change. In: Douglas I, Goode D, Houck M, editors. Handbook of urban ecology. Florence: Routledge; 2011.

40. Dramstad WE, et al. New York, Springer-Verlag, 1999. Landscape Ecology Principles in Landscape Architecture and Land Use Planning Duerksen, Christopher and Snyder, Cara. Washington D.C: Island Press; 1996.

41. Foster J, Lowe A, Winkelman S. The value of green infrastructure for urban climate adaptation. Washington, DC: Center for Clean air Policy; 2011.

42. Fulmer J. What in the world is infrastructure? PEl Infrastructure Investor; 2009. p. 30-2

43. Gill SE, Handley JF, Ennos AR, Pauleit S. Adapting cities for climate change: the role of the green infrastructure. Built Environ. 2007:33:115-33.

44. Hellmund PC, Smith DS. Johnson B, Hill K, editors. (July 2001) Designing greenways: sustainable landscapes for nature and people. Washington, D.C.: Island Press. p. 2006

45. Beatley T. Biophilic cities: integrating nature into Urban Design and planning: Island Press; 2011.

46. Desha C, Reeve A, Newman P, Beately T. Guest editorial: urban nature for resilient and liveable cities. Smart Sustainable Built Environ. 2016;5(1):1-4.

47. Wilson EO. Biophilia: the human bond with other species. Cambridge: Harvard University Press; 1986.

48. Kellert S. Biophilic urbanism: the potential to transform. Smart Sustainable Built Environ. 2016;5(1):4-8

49. Dlani A, ljeoma E, Zhou L. Implementing the Green City policy in municipal spatial planning: the case of Buffalo City metropolitan municipality. Africa's Publ Service Delivery Performance Rev. 2015;3(2):149-82.

50. Economist Intelligence Unit, G Britain, Aktiengesellschaft S. Asian Green City index: assessing the environmental performance of Asia's major citiesCitiesCDP Cities Global Report. 2011.

51. Taylor L, Hochuli DF. Defining greenspace: multiple uses across multiple disciplines. Landsc Urban Plan. 2017:158:25-38.

52. Firehock K. Strategic green infrastructure planning: a multi-scale approach Washington, D.C.: Island Press; 2015

53. McHarg I. Design with nature. Hoboken: Wiley; 1969

54. Kellert S, Wilson EO. The biophilia hypothesis. Washington, DC: Island Press; 1993.

55. Kellert S. Birthright: people and nature in the modern world. New Haven: Yale University Press; 2012.

56. El-Baghdadi O, Desha C. Conceptualising a biophilic services model for urban areas. Urban Forestry Urban Greening. 2017;(27):399-408. 
57. Newman P, Hargroves K, Desha C, Reeve A, El-Baghdadi O, Bucknum M. Mariela, Soderlund J, Salter R, Beatley T. Can biophilic urbanism deliver strong economic and social benefits in cities? An economic and policy investigation into the increased use of natural elements in urban design. Project 1.5 Industry Report to the the Sustainable Built Environment National Research Centre (SBEnrc), Australia. 2012.

58. El-Baghdadi O. Exploring the economic business case for incorporating biophilic urbanism. Doctoral dissertation. Brisbane: Queensland University of Technology; 2016.

59. El-Baghdadi O, Desha C, Hargroves K. Engaging decision makers in the business case for biophilic urbanism. In: Reeve A, Kabisch N, Artmann M, Larondelle $\mathrm{N}$, editors. Human-environmental interactions in cities: challenges and opportunities of urban land use planning and green infrastructure. United Kingdom: Cambridge Scholars Publishing; 2014. p. 12-26.

60. Millennium Ecosystem Assessment. Ecosystems and human well-being, vol. 5. Washington, DC: Island Press; 2005.

61. Lobo G. Ecosystem functions classification. 2001. Cited September 2002 Available at http://gasa3.dcea.fct.unl.pt/ecoman/delphi/.

62. de Groot RS, Wilson MA, Boumans RMJ. A typology for the classification, description and valuation of ecosystem functions, goods and services. Ecol Econ. 2002;41:393-408.

63. Kristensen P. "The DPSIR framework." National Environmental Research Institute, Denmark. Department of Policy Analysis, European topic Centre on water, European Environment Agency, Paper Presented at the 27-29 September 2004 Workshop on a Comprehensive / Detailed Assessment of the Vulnerability of Water Resources to Environmental Change in Africa Using River Basin Approach. Nairobi: UNEP Headquarters; 2004.

64. Roy S, Byrne J, Pickering C. A systematic quantitative review of urban tree benefits, costs, and assessment methods across cities in different climatic zones. Urban For Urban Green. 2012;11(4):351-63.

65. Phillips A, editor. Economic values of protected areas: guidelines for protected area managers. Gland and Cambridge: IUCN - The World Conservation Union; 1998.

66. Lee ACK, Jordan HC, Horsley J. Value of urban green spaces in promoting healthy living and wellbeing: prospects for planning. Risk Manag Healthc Policy. 2015;8:131.

67. Habitat UN. "World cities report 2016." urbanization and development: emerging futures. New York: Pub. United Nations; 2016.

\section{Publisher's Note}

Springer Nature remains neutral with regard to jurisdictional claims in published maps and institutional affiliations.

Ready to submit your research? Choose BMC and benefit from:

- fast, convenient online submission

- thorough peer review by experienced researchers in your field

- rapid publication on acceptance

- support for research data, including large and complex data types

- gold Open Access which fosters wider collaboration and increased citations

- maximum visibility for your research: over $100 \mathrm{M}$ website views per year

At $\mathrm{BMC}$, research is always in progress.

Learn more biomedcentral.com/submissions 